\title{
Hypocalcaemia in autoimmune haemolytic anaemia and pernicious anaemia
}

\author{
A.A. Baba and D. Maharaj \\ Royal Infirmary, Glasgow G4 OSF, UK.
}

\begin{abstract}
Summary: A 71 year old woman presented with hypocalcaemia in association with autoimmune haemolytic anaemia and pernicious anaemia. The hypocalcaemia resolved only when the haemolytic anaemia and pernicious anaemia were successfully treated. The possible pathogenic mechanisms are discussed.
\end{abstract}

\section{Introduction}

Electrolyte and metabolic abnormalities including hypocalcaemia are recognized complications of haematological malignancies especially during treatment. ${ }^{1,2}$ It is not generally appreciated that similar abnormalities may occur in benign haematological conditions. Hypocalcaemia associated with pernicious anaemia has been reported previously. ${ }^{3}$

This is the first report of the occurrence of unexplained hypocalcaemia in a patient with autoimmune anaemia and pernicious anaemia.

\section{Case report}

A 71 year old woman presented in June 1985 with a three month history of general malaise and weakness. Examination showed a well-hydrated woman who had marked pallor and mildly icteric sclerae. A goitre was palpable but the patient was clinically euthyroid and Chvostek's and Trousseau's signs were negative.

Investigations showed: haemoglobin $5.5 \mathrm{~g} / \mathrm{dl}$, white blood count $10.5 \times 10^{9} / 1$, platelet count $275 \times 10^{9} / 1$, mean cell volume $121 \mathrm{fl}$, mean cell haemoglobin $37 \mathrm{pg}$ and $18 \%$ reticulocytes. Peripheral blood film showed oval macrocytosis, microspherocytes, polychromasia and hypersegmented neutrophils. Serum $B_{12}$ was reduced at $88 \mathrm{pg} / \mathrm{ml}$ while serum and red cell folate levels were normal. A Schilling test with intrinsic factor confirmed a diagnosis of pernicious anaemia. The

Correspondence: D. Maharaj, M.R.C.P.(UK), M.R.C.Path., Department of Haematology, Memorial Hospital, Darlington DL3 6HX, UK.

Accepted: 25 June 1987 direct antiglobulin test was strongly positive with IgG and C3d coating. Haptoglobin concentration was less than $0.15 \mathrm{~g} / \mathrm{dl}$ (normal $0.26-5.0 \mathrm{~g} / \mathrm{dl}$ ). Sternal marrow aspirate showed a hypercellular marrow with megaloblastic erythropoiesis.

Biochemical investigations were as follows: normal serum electrolytes, urea $5.9 \mathrm{mmol} / \mathrm{l}$, creatinine $110 \mu \mathrm{mol} / 1$, direct bilirubin $25 \mu \mathrm{mol} / 1$, serum calcium $1.4 \mathrm{mmol} / \mathrm{l}$, phosphate $1.8 \mathrm{mmol} / \mathrm{l}$. Serum magnesium, alkaline phosphatase transaminases and albumin levels were all normal. Serum parathyroid hormone (PTH) levels ranged from 460 to $550 \mathrm{ng} / \mathrm{ml}$ (normal: $<600 \mathrm{ng} / \mathrm{ml}$ ), calcitonin $20 \mathrm{ng} / 1$ (normal 10-45 g/l), 25-hydroxycholecalciferol $44 \mathrm{nmol} / 1$ (normal $15-100 \mathrm{nmol} / \mathrm{l}$ ) and 1,25-dihydroxycholecalciferol was $88 \mathrm{pmol} / 1$ (normal 20-120 pmol/1). Thyroid function tests revealed a sick euthyroid pattern with normal thyroxine and thyroid stimulating hormone levels but low triiodothyronine at $0.6 \mathrm{nmol} / 1$ (normal 0.9 $2.8 \mathrm{nmol} / \mathrm{l})$.

Tests for parietal cell, intrinsic factor, thyroid and parathyroid antibodies were negative. Isotope thyroid scan showed a multinodular goitre.

The patient was treated with prednisolone $60 \mathrm{mg} /$ day. After 3 weeks of therapy there was no reduction in haemolysis and azathioprine $150 \mathrm{mg} /$ day was added. Hydroxocobalamin was given with folate supplements during the period of haemolysis.

Hypocalcaemia was treated with oral calcium gluconate and $1 \alpha$-hydroxycholecalciferol $1 \mu \mathrm{g} / \mathrm{day}$. After 8 weeks of therapy the haemoglobin concentration had risen to $11.5 \mathrm{~g} / \mathrm{dl}$ with reticulocytes and biochemical abnormalities had corrected with serum calcium $2.16 \mathrm{mmol} / 1$ and phosphate at $0.90 \mathrm{mmol} / \mathrm{l}$. 
Calcium supplements and $1 \alpha$-hydroxycholecalciferol were stopped and the patient was discharged on prednisolone $10 \mathrm{mg} /$ day and azathioprine $150 \mathrm{mg} /$ day. Steroid therapy was later withdrawn and during 9 months of follow-up she has remained in haematological remission with normal biochemical indices on azathioprine alone.

\section{Discussion}

The exact cause of the transient hypocalcaemia in our patient is uncertain. There was no clinical or biochemical evidence of malabsorption. Hypomagnesaemia can lead to hypocalcaemia both by inhibiting secretion of PTH and impairing end organ response to $\mathrm{PTH}^{4}$ but these mechanisms were excluded as repeated magnesium levels were normal.

Hypergastrinaemia, a feature of pernicious anaemia may also lead to hypocalcaemia by stimulating calcitonin secretion which then suppresses mobilisation of calcium from bone. ${ }^{5,6}$ The increased level of gastrin in patients with

\section{References}

1. Mir, M.A. \& Delamore, I.W. Metabolic disorders in acute myeloid leukaemia. $\mathrm{Br} J$ Haematol 1978, 40: 79-92.

2. Freedman, D.B., Shannon, M., Dandona, P., Prentice, H.G. \& Hoffbrand, A.V. Hypoparathyroidism and hypocalcaemia during treatment for acute leukaemia. Br Med J 1982, 284: 700-702.

3. Fairris, G.M., Mason, P.O. \& Fairris, N. Hypocalcaemia in pernicious anaemia. $\mathrm{Br}$ Med $J$ 1984, 288: 607.

4. Agus, Z.A., Wasserstein, A. \& Goldfarb, S. Disorders of calcium and magnesium haemostasis. Am J Med 1982, 72: 473-488. pernicious anaemia is not, however, high enough to affect secretion of calcitonin. ${ }^{5}$ The calcitonin level in our patient was normal.

The occurrence of hypocalcaemia and hyperphosphataemia in the absence of significant renal impairment is classically thought to be diagnostic of hypoparathyroidism or pseudohypoparathyroidism. The PTH levels in our patient were normal though it could be argued that she had relative hypoparathyroidism with inappropriately low parathormone for the prevailing serum calcium concentration. An autoimmune aetiology could explain the hypoparathyroidism, the pernicious anaemia and the autoimmune haemolytic anaemia and appears to be the most likely explanation for the hypocalcaemia in our patient. Control of the autoimmune process with steroids and azathioprine may explain the return of the calcium level to normal.

Although the exact mechanism of the transient hypocalcaemia in autoimmune haemolytic anaemia and pernicious anaemia is uncertain, clinicians should be aware of this association so that appropriate therapeutic intervention can be taken to prevent morbidity from significant hypocalcaemia.
5. Brandsberg, M., Nielson, H.E., Brandsborg, D., Olsen, K.J. \& Lovgran, N.A. The role of serum gastrin in the secretion of calcitonin; studies in patients with pernicious anaemia and healthy subjects. Scand $J$ Gastroenterol 1980, 15: 23-28.

6. Lamers, C.B.H., Haking, W.H., Thiem, T.R. \& Tongren, J.H.M. Serum concentrations of immunoreactive calcitonin in patients with hypergastrinaemia. Digestion 1980, 20: 389-382. 